\title{
READINESS OF HUMAN RESOURCE, LOGISTICS, AND FINANCE IN HANDLING PANDEMIC COVID-19 AT BHAKTI WIRA TAMTAMA TNI HOSPITAL, SEMARANG
}

\author{
Rianti Merviane Erungan
}

\begin{abstract}
Hospital Administration Study Program, Faculty of Public Health, Universitas Indonesia, Depok, West Java
\end{abstract}

\begin{abstract}
Background: Covid-19 is a highly infectious disease. In response to the estimated potential impact of COVID-19, standardized hospital preparedness and readiness measures are essential to contain nosocomial outbreaks and operate hospitals safely. This study aimed to investigate the human resource, logistics, and finance readiness in handling pandemic Covid19 at Bhakti Wira Tamtama TNI hospital, Semarang.

Subjects and Method: A qualitative study with a phenomenological approach was conducted at Bhakti Wira Tamtama TNI AD hospital, Semarang, Central Java, from April to May 2020. A total of 3 informants was selected by purposive sampling. The data were collected by in-depth interview, document review, and WHO Hospital Readiness questionnaire. The data were analyzed by classification, compilation, and tabulation compared to the WHO Hospital Readiness checklist.

Results: Based on the WHO Hospital Readiness checklist, Bhakti Wira Tantama TNI AD hospital had sufficient human resources readiness for a capacity of 160 patients. But it showed limited readiness in logistics and financial resources in handling the Covid-19 pandemic.

Conclusion: Bhakti Wira Tantama TNI AD hospital had sufficient human resource readiness but limited logistics and financial resources in handling the Covid-19 pandemic.
\end{abstract}

Keywords: COVID-19, hospital readiness, World Health Organization (WHO)

\section{Correspondence:}

Rianti Merviane Erungan. Hospital Administration Study Program, Faculty of Public Health, Universitas Indonesia. Jl. Margonda Raya, Pondok Cina, Beji, Depok, Java Barat, 16424.

Email: riantimaria@yahoo.com. Mobile: +628118899922

The $7^{\text {th }}$ International Conference on Public Health

Solo, Indonesia, November 18-19, 2020 340

https://doi.org/10.26911/the7thicph.04.25 